\title{
Taxes, start-up costs, and innovative entrepreneurship
}

\author{
Pourya Darnihamedani • Joern Hendrich Block • \\ Jolanda Hessels • Aram Simonyan
}

\begin{abstract}
Prior research investigates the role of start-up costs and taxes with regard to entrepreneurship. Yet, little distinction is made regarding the type of entrepreneurship, particularly innovative versus non-innovative entrepreneurship. We shall argue that start-up costs and taxes are associated in different ways with innovative versus non-innovative entrepreneurship. Taxes being recurring costs should mainly relate to innovative entrepreneurship, whereas start-up costs being one-off costs should mainly relate to non-innovative entrepreneurship. Analyzing a dataset of 632,116 individuals, including 43,223 entrepreneurs from 53 countries, we can partially confirm our predictions. Corporate taxes show a negative relationship with innovative entrepreneurship, whereas income taxes seem to have no
\end{abstract}

Electronic supplementary material The online version of this article (https://doi.org/10.1007/s11187-018-0005-9) contains supplementary material, which is available to authorized users.

P. Darnihamedani

Tilburg School of Economics and Management, Tilburg

University, Tilburg, The Netherlands

J. H. Block · J. Hessels $(\bowtie)$

Erasmus School of Economics, Erasmus University Rotterdam, Rotterdam, The Netherlands

e-mail: hessels@ese.eur.nl

J. H. Block

University of Trier, Trier, Germany

\section{A. Simonyan}

International Scientific Educational Centre, National Academy of Science of the Republic of Armenia, Yerevan, Republic of Armenia relationship. High start-up costs have a positive relationship with innovative entrepreneurship, although this finding only holds true in cross-sectional investigations. Our paper contributes to the discussion on how governmental regulation and taxes relate to entrepreneurship.

Keywords Innovative entrepreneurship · Corporate taxes $\cdot$ Personal income taxes $\cdot$ Start-up costs $\cdot$ GEM

JEL codes $\mathrm{L} 26 \cdot \mathrm{H} 24 \cdot \mathrm{D} 24$

\section{Introduction}

A large prior literature has investigated how government regulations, policies, and actions relate to entrepreneurship (see Blackburn and Schaper (2016), for a summary). Within this literature, many studies have investigated the role of taxes and start-up costs (Gentry and Hubbard 2000; Djankov et al. 2002; Klapper et al. 2006; Cullen and Gordon 2007; Braunerhjelm and Eklund 2014; Block 2016). Both taxes and start-up costs can be directly influenced by government policy and are shown to have strong relationships with entrepreneurship rates. So far, no study has investigated the role of taxes and start-up costs with regard to innovative entrepreneurship. This is an important oversight, as we believe that the distinction between innovative and non-innovative entrepreneurship is an important one. While many policy-makers and scholars use the terms innovation and entrepreneurship interchangeably (Dreher and 
Gassebner 2013; Autio et al. 2014) and even try to stimulate one in the hope of getting more of the other, only very few entrepreneurs innovate (Reynolds et al. 2005; Block et al. 2017). Yet, prior research shows that, in particular, such innovative entrepreneurs are responsible for economic growth and development (Autio et al. 2014; Block et al. 2017).

We shall argue that start-up costs and taxes are associated in different ways with innovative entrepreneurship. Start-up costs such as notary charges or registration costs are one-off costs that increase the barriers of entry into entrepreneurship. High start-up costs are usually associated with low entrepreneurship rates. Yet, high start-up costs may not only influence the quantity of entrepreneurship but also the quality and type of entrepreneurship. In fact, high start-up costs may lead to a positive selection of those individuals who are highly motivated and expect high incomes from entrepreneurship. Monteiro and Assunção (2012), Branstetter et al. (2014), and RostamAfschar (2014) find that low start-up regulations attract low quality entrepreneurs with low expected returns. We argue that innovative entrepreneurs expecting high returns (Schumpeter 1934) are more willing, compared to other entrepreneurs, to incur high start-up costs. In addition, they are usually well positioned to attract external funding (Desai et al. 2003). Taxes, in turn, represent recurring costs reducing the gains from innovation and entrepreneurial profit. They have a deterrent and discouraging effect particularly for risk-taking entrepreneurs with innovative ideas (Hansson 2012). Taxes reduce the expected return on innovation and, thus, discourage innovative entrepreneurship. High tax rates partially remove the "prize" of introducing a new product to the market, while entrepreneurs remain responsible and liable when their ideas fail (Gentry and Hubbard 2000; Cullen and Gordon 2007). In our investigations, we distinguish between income and corporate taxes and how they are associated with innovative entrepreneurship. While income taxes concern the income from unincorporated firms, corporate taxes refer to the income from incorporated firms (Cullen and Gordon 2007). Most innovative entrepreneurs register their businesses as corporations in order to grow faster and attract external funding. Thus, there is reason to believe that corporate taxes should have a stronger relationship with innovative entrepreneurship than income taxes have.

To investigate how start-up costs and taxes relate to innovative entrepreneurship, we use the Global Entrepreneurship Monitor (GEM) dataset, which is composed of 632,116 individuals, including 43,223 entrepreneurs from 53 countries from 2004 to 2011. Conducting both cross-sectional and longitudinal regressions, we can partially confirm our predictions. Corporate taxes show a negative relationship with innovative entrepreneurship, whereas income taxes seem to show no relationship. High start-up costs seem to have a positive relationship with innovative entrepreneurship, although this finding seems to only hold true in cross-sectional and not in longitudinal investigations.

The rest of the paper is structured as follows: the next section develops hypotheses on how start-up costs and taxes relate to innovative entrepreneurship. Then, we describe our data sources, variables, and methods. Subsequently, we present our main results, together with a number of robustness checks. In the final section, we present the main conclusions, implications, and limitations of the study.

\section{Theory and hypotheses}

\subsection{Start-up costs and innovative entrepreneurship}

Start-up regulations are procedures and requirements imposed by governments for starting a business. Startup regulations are established to ensure that new companies meet minimum requirements to provide goods or services to the market (SRI International 1999). Several studies, particularly those rooted in a neo-classical economics perspective, suggest that minimal start-up regulations encourage entrepreneurship (Djankov et al. 2002; Klapper et al. 2006). Djankov et al. (2002) show that countries with high start-up regulations have high levels of corruption and low qualities of public or private goods. A number of studies (e.g., Bruhn 2011; Yakovlev and Zhuravskaya 2013) found that reforms in entry regulations can increase competition and Total Factor Productivity (TFP). Yet, there is also a positive aspect of entry regulations. According to Scarpetta et al. (2002), high entry and adjustment costs in Europe may stimulate a pre-market selection of business plans with less market experimentation. They also add that there is no evidence in their data that one model (i.e., low entry barriers) dominates the other (i.e., high entry barriers) in terms of aggregate performance. A few studies (e.g., Branstetter et al. 2014; Rostam-Afschar 2014; Schulz et al. 2016) focus on characteristics of new entrepreneurs and the quality of their ideas after reforms in entry 
regulations. In fact, the assumption that lowering startup costs leads to the entry of higher quality entrepreneurs has been challenged by these studies (Kaplan et al. 2011; Branstetter et al. 2014; Rostam-Afschar 2014). Rostam-Afschar (2014) uses a sample of German individuals and finds that reducing entry regulations leads to a higher number of untrained workers becoming entrepreneurs. This is primarily because high entry barriers deter such untrained workers from becoming entrepreneurs. Trained workers, with a higher level of human capital, have sufficient means to become entrepreneurs, even if the entry barriers are considerably high (Davidsson and Honig 2003).

We argue that when start-up costs are high, it is in particular those individuals with not so promising or novel ideas who are deterred to become entrepreneurs. Individuals with such ideas do not expect high returns, and so are less willing to incur high one-off entry costs. Reducing start-up costs makes it easier and more attractive for them to become entrepreneurs. In line with this, Schulz et al. (2016) found that entry deregulation through the introduction of the one-stop shop policy in Mexico has led to the entry of disproportionally more part-time than full-time entrepreneurs. Part-time entrepreneurs often do not have innovation as their main goal but rather start their venture to earn a side income next to their main job (Block and Landgraf 2016). It also often coincides with a high-risk aversion which does not go well with innovative entrepreneurship. Part-time entrepreneurs often do not have enough time, courage, and dedication to build an innovative new product and properly test it in the market (Raffiee and Feng 2014). We shall argue that part-time entrepreneurs are among those entrepreneurs who are particularly deterred by high startup costs. The situation is different for full-time entrepreneurs with innovative business ideas, who may be willing to bear high start-up costs because they expect high returns from their ventures (Gregg and Parthasarathy 2017). Entry costs are one-off costs and are not directly linked to the rewards from their innovative venture. In addition, individuals with innovative ideas usually are in a good position to attract external financing such as debt financing from banks or equity financing from venture capitalist or business angels (Desai et al. 2003). Such funding allows them to overcome high start-up costs and facilitates entrepreneurial entry (Ho and Wong 2007). Finally, by incurring high start-up costs innovative entrepreneurs can signal to banks and other financing providers that they believe in their ideas and the rewards that come with them. This signaling theory argument applies less to non-innovative entrepreneurs who typically do not need external financing to pursue their venture. Higher willingness to pay start-up costs signals higher quality and may be interpreted as commitment of the entrepreneur to the business opportunity (Suchman 1995), particularly from the perspective of resource providers and other stakeholders. When a new firm takes advantage of relaxed entry requirements, it may fail to signal that it has the certifications, resources, and accomplishments needed to succeed. Lower entry requirements can particularly undermine the ability of innovative entrepreneurs to gather resources (Hallen and Eisenhardt 2012), and it might be more difficult to obtain funding for innovative ideas (De Meza and Webb 1999). Banks do not know the quality of the entrepreneurs' projects due to asymmetric information and the high volume of entrepreneurs and may assume because of inexpensive entry that there are many low-ability entrepreneurs.

To summarize the previous arguments, we propose the following hypothesis:

Hypothesis 1: Start-up costs have a positive relationship with innovative entrepreneurship.

\subsection{Taxes and innovative entrepreneurship}

Designing a tax structure is a complex task due to its various effects on citizens, including business owners (Balliamoune-Lutz and Garello 2014). Governments face an important dilemma when making decisions about tax rates. On the one hand, they need to collect sufficient taxes to provide high-quality public goods and services for their citizens. On the other hand, they want to avoid the danger of deterring economic growth by onerous taxation (Lee and Gordon 2005).

The tax system affects entrepreneurial decisions and often taxes successful ventures at a disproportionally higher rate than unsuccessful ones (Gentry and Hubbard 2000). A recent study by Wen and Gordon (2014) shows that tax progression influences the occupational choice between self-employment and paid employment, so that with more progressivity, individuals are less likely to opt for self-employment. This finding indicates how career decisions of individuals can depend on tax rates, so that with high tax rates (and with more progressivity), the opportunity costs of entrepreneurship will increase. Although prior studies suggest 
that entrepreneurs have more opportunities to avoid paying taxes than employees (Kamleitner et al. 2012), they mentally perceive taxes as payments "out of pocket." Unlike employees who are rather passive in receiving information about the amount of taxes they pay, business owners think of taxes as a loss by looking at their gross income as the outcome of their work. To make matters worse, taxes are recurring costs taking away part of the gross income periodically. People cognitively separate various sources of costs and incomes and constitute several mental accounts for such sources (Thaler 1999). Since taxes are seen mainly by entrepreneurs to form part of the mental income account, payment of taxes is painful and perceived as reducing income. In addition to tax evasion, taxes may influence other strategic decisions of entrepreneurs such as their willingness to introduce new ideas and new products.

There are two main types of taxes on entrepreneurs depending on the legal type of their venture. In many countries (e.g., the Netherlands and the USA), profits are taxed under the corporate tax system when the business is incorporated (e.g., limited liability corporations), while income taxes are imposed on individual earnings. The latter concerns unincorporated firms (e.g., sole proprietorship) (Bruce and Mohsin 2006; Block 2016). We argue that both types of taxes have deterring effects on innovative entrepreneurship.

\subsubsection{Corporate taxes and innovative entrepreneurship}

Corporate tax refers to the tax that corporations pay on their taxable income. This tax is to be distinguished from capital gains tax (i.e., to be paid on profits that an investor receives when he or she sells a capital asset for a higher price than the purchase price), personal income tax (to be paid on earned income by the self-employed or wage workers), and capital income tax (to be paid on dividend or interest income) (Block 2016). We argue that since corporate tax is a frequently recurring cost, it can have a deterrent effect on innovative entrepreneurship. There are a number of reasons why this deterrent effect may occur.

First, high corporate tax reduces the prize of innovation because it usually increases with the venture's profit, sometimes even in a progressive manner. In fact, high tax re-distributes wealth from successful innovative entrepreneurs to other citizens in society with low or no income (e.g., the unemployed) (Gentry and Hubbard 2000; Baumol et al. 2007). Corporate tax can discourage entrepreneurs from engaging in innovative yet risky activities (Balliamoune-Lutz and Garello 2014; Clingingsmith and Shane 2016). When a tax code taxes profits more heavily than it provides tax credits for losses of corresponding size, policy-makers create an incentive to engage in activities that generate income with lower variability. This incentive increases with the size of the marginal tax rate. The formal entry of innovative entrepreneurs largely depends on their expected returns on innovation. Because corporate tax will repeatedly take away a portion of the income from innovation, high tax levels are expected to discourage individuals with innovative ideas from starting a business. In such situations, individuals with innovative ideas may either become intrapreneurs or just give up on their ideas due to its low (monetary) rewards.

Second, high corporate tax rates can have an adverse impact on the entrepreneurs' ability to invest in innovation. Prior research has found that one of the main sources of investment capital for entrepreneurs, especially during the early stages of the venture, are retained business earnings (Henrekson and Sanandaji 2011). This is mainly due to the high agency costs of other sources of investment capital. High corporate tax rates take away part of the start-up's income that could be invested in innovation. Moreover, low corporate tax rates create incentives for external investments in innovative ventures. This is mainly because external investors can generate higher returns on their investments. Such lower tax rates and tax breaks have attracted, for example, angel investors in a number of American states to invest in innovative start-ups (Chatterji et al. 2014). To summarize, high levels of corporate taxation may make it more difficult for entrepreneurs to finance their innovative ideas.

Third, high tax rates may be associated with extensive safety net programs, such as generous unemployment benefits and universal health insurance (Baumol et al. 2007). A tax-financed welfare system may reduce household savings and may limit entrepreneurial investments and capital accumulation (Fölster 2002), which are important determinants of a country's level of innovative entrepreneurship (Schumpeter 1934; Baumol et al. 2007). In addition, such safety net programs usually point to a culture that does not appreciate and reward hardworking individuals (Baumol et al. 2007). This could further lead to a lower tendency among entrepreneurs to innovate, because innovation requires much effort to arrange a "new combination of means of production" (Schumpeter 1934). 
Building on these three lines of arguments, we propose the following hypothesis:

Hypothesis 2: Corporate taxes have a negative relationship with innovative entrepreneurship.

\subsubsection{Income taxes and innovative entrepreneurship}

Income tax concerns a different group of entrepreneurs than corporate tax does. It applies to individual earnings taken from unincorporated firms (Block 2016), which are typically less growth oriented than other firms (Haans and van Witteloostuijn 2016). An important difference between income and corporate tax is that in many countries including the USA, losses from personal income are deductible from other income under the personal tax code but not under the corporate tax code (Cullen and Gordon 2007; Hansson 2012). Cullen and Gordon (2007) found that a cut in the personal tax rate would reduce entrepreneurial risk taking. This is in fact a reason for the severe impact of high corporate rates on the individuals' decisions for incorporation while those under the income tax scheme may view entrepreneurial risks differently. In fact, individuals are more likely to undertake innovative high risk-high gain activities under conditions of low personal liability (Harhoff et al. 1998). Hence, when entrepreneurs are not liable to their losses under the income tax scheme, they may be more likely to engage in innovation.

Despite the differences between income and corporate tax, two of the three arguments concerning the negative effect of corporate taxes on innovative entrepreneurship also apply to income taxes. Like with corporate taxes, higher income taxes also reduce the expected returns from entrepreneurship and subsequently the prize and motivation for innovation. Prior research shows that also among entrepreneurs with unincorporated firms, there are a number of entrepreneurs with truly innovative business ideas: De Vries and Koster (2013) and van Stel and de Vries (2015) show that solo self-employed are, by and large, as innovative as small and medium sized enterprises (SMEs). Next to this demotivation effect, high income taxes also reduce the amount of funds available for investments in innovation. With unincorporated businesses, most of those funds come from prior savings of the entrepreneur, which are, however, less likely to be build up in case of high income taxes.

Hence, we put forward the following hypothesis:

Hypothesis 3: Income taxes have a negative relationship with innovative entrepreneurship.

\section{Data and method}

\subsection{Data sources}

We use both individual- and country-level data. Our individual-level data are from entrepreneurs who have participated in the Adult Population Survey (APS) of the Global Entrepreneurship Monitor (GEM). The data covers 53 countries from 2004 to 2011. GEM is the largest cross-country study of entrepreneurial activity, aspirations, and attitudes (Reynolds et al. 2005). It collects data on individuals about different aspects of their entrepreneurial activity, such as the innovativeness of their ventures, as well as their personal start-up motivations, entrepreneurial ambitions, and human capital characteristics, which make the GEM data suitable for use in our research.

At the country level, we use the World Bank Doing Business (WBDB) database and the World Competitiveness Yearbook (WCY) for information on start-up costs and tax rates. The WBDB database contains several measures of business regulations and their enforcement for 155 countries from 2004 to the present. These measures demonstrate the regulatory expenses and procedures of undertaking business and have been used in prior research to analyze regulatory influences on the productivity and growth of entrepreneurs (e.g., Dreher and Gassebner 2013; Braunerhjelm and Eklund 2014). We use the WCY for information about corporate and personal income tax rates, as well as for some control variables (e.g., GDP growth, GDP per capita). WCY includes annual data for 18 years for more than 50 countries that participate in the executive survey conducted by the IMD World Competitiveness Center. Several previous studies have used WCY measures to study the impact of country-level factors on entrepreneurship (e.g., van Stel et al. 2007; Hessels et al. 2008).

\subsection{Sample}

The total GEM sample for 2004 to 2011 is composed of 689,399 individuals aged 18 to 64 , including (earlystage and established) entrepreneurs, employees, unemployed individuals, students, and retirees. Of these, 57,796 persons are early-stage entrepreneurs $(8.4 \%)$ (i.e., individuals who are setting up businesses), as well as entrepreneurs who have started their own business in the last 42 months. For the purpose of this study, we focus on whether such early-stage entrepreneurs (that 
we henceforth call "entrepreneurs") are innovative (see also the description of variables as follows).

Table A.1 in the electronic supplementary material shows the number of individuals and entrepreneurs per country and distinguishes between innovative and noninnovative entrepreneurs.

\subsection{Variables (individual-level regressions)}

Our dependent variable is innovative entrepreneur. This variable is measured at the individual level, based on a question in the GEM survey asking entrepreneurs whether they provide a new product or service to the market. The variable is a dummy variable that takes the value one when the product or service offered is perceived by the entrepreneur to be new to customers and takes the value zero otherwise.

Our main independent variables are start-up costs and corporate and income tax, which are measured at the country level. Start-up costs reflect the expenses required by law to register a new venture in a country. Tax refers to the (logarithm of) corporate and personal income tax rates in a country. Table 1 provides a more detailed overview and description of our independent variables. Tables A.1 and A.2 in the electronic supplementary material provide more insights into the values of the dependent and independent variables per country and per year, respectively. ${ }^{1}$

One might ask why the share of innovative entrepreneurship is $41.8 \%$ in Chile or $33.9 \%$ in Jordan while it is, for example, $11.6 \%$ in the UK. The explanation is that advancement of an economy does not necessarily mean that its entrepreneurs are innovative. Entrepreneurs can still be mainly imitative or adopters in an advanced economy so that the ratio of innovative entrepreneurs would be low. In developing countries, there is more room to innovate in the market as many ideas are not yet tested and can be learned/copied from more developed countries. Hence, ideas in developing countries might not be globally innovative, but they are at least new in their local market.

In addition, we add to the regression model a number of individual and country-level control variables that are common determinants of innovative entrepreneurship (Acs and Audretsch 1987; Koellinger 2008; Anokhin

\footnotetext{
${ }^{1}$ These tables show the differences within countries.
}

and Schulze 2009; Autio et al. 2014; Fritsch and Wyrwich 2018). At the individual level, the following variables are included: formal education (a dummy variable that indicates whether entrepreneurs have a university education), entrepreneurial networks (a dummy variable indicating whether the entrepreneur knows someone personally who started a new business in the last 2 years), perception of entrepreneurial skills (a dummy variable indicating whether the entrepreneur perceives him- or herself to have relevant skills, knowledge, and experience for setting up a business), recent prior entrepreneurship experience (a dummy variable that indicates whether someone has quit as an entrepreneur in the past 12 months), established business ownership (a dummy variable that equals one if the respondent owns a business older than 42 months), and gender (a dummy variable that equals one for males). Age and age squared are also included. We further added "year" and "industry" as dummy variables to the regression model. The following industries are distinguished: business services (financial intermediation, real estate, renting, and business activities), consumer-oriented services (hotels and restaurants, other services), extractive industries (agriculture, fishing, mining, and quarrying), and transforming (manufacturing, electricity, gas, water, construction, trade, repairs, transportation, storage, and communication). At the country level, we include GDP growth and the (logarithm of) GDP per capita, which are both taken from the WCY database. After removing observations with missing values, we retained a sample of 632,116 individuals including 43,223 entrepreneurs.

\subsection{Regression methods}

We analyze our data at both individual and country levels. At the individual level, we run Heckman probit regressions; at the country level, we employ fixed effect panel regressions and (Bayesian) first-difference regressions.

\subsubsection{Individual-level cross-sectional regression: Heckman probit model}

Our dependent variable innovative entrepreneur is binary, and we use various probit regressions. We cluster the individual-level data by countries to avoid underestimating standard errors (Huber and Stanig 2011). Furthermore, we employ a Heckman probit model to reduce a potential selection bias when assessing the influence of start- 
Table 1 Data sources for the main country-level variables

\begin{tabular}{|c|c|c|}
\hline Variable & Description & Source \\
\hline Start-up costs & $\begin{array}{l}\text { The average costs of obtaining legal status to operate a firm, measured as } \\
\text { a percentage of per capita income. It contains all recognizable official } \\
\text { expenses such as fees, costs of forms and procedures, photocopies, fiscal } \\
\text { stamps, and legal and notary charges }\end{array}$ & WBDB \\
\hline Corporate tax rate & Maximum corporate tax rate, calculated on profit before tax & WCY \\
\hline Income tax rate & Maximum personal income tax rate as a percent of the individual's income & WCY \\
\hline
\end{tabular}

up costs and taxes on the likelihood for entrepreneurs to be innovative. This is mainly because start-up costs and taxes could affect the entry of individuals into entrepreneurship (Gentry and Hubbard 2000; Djankov et al. 2002; Wen and Gordon 2014), in addition to their effect on innovative entrepreneurship. As such, trying to estimate the influence of start-up costs and taxes on an entrepreneur's likelihood to innovate may lead to biased estimators when such potential selection bias is not taken into account. Heckman correction (probit) models are used to address this methodological issue. Additionally, we test for the presence of a selection bias through likelihood ratio tests: The likelihood ratio test of rho (which compares the log likelihoods of the selection plus outcome models with the log likelihood of the probit model with sample selection) confirms that a Heckman model is indeed necessary (Table 2).

The Heckman model has one selection and one outcome equation. The selection equation (the first stage) estimates entry into entrepreneurship, including all the abovementioned individual- and country-level predictors. We also add the individuals' employment status (dummy variables indicating whether someone is employed, unemployed, a student, or a retiree) to the selection equation. The outcome equation (i.e., the second stage) estimates whether or not an entrepreneur is innovative. The Heckman probit model is similar to other Heckman correction models (Heckman 1976, 1979; Puhani 2000) in how it corrects for selection bias, except that the outcome-dependent variable is a dummy variable and not a metric variable. The main control variables correspond to Braunerhjelm and Eklund (2014).

\subsubsection{Country-level longitudinal regressions}

Next to the individual level, we analyze our data in an aggregated form at the country level and thereby employ a longitudinal perspective. To understand the effect of our predictors on the outcome variable within each country, we estimate panel data regressions using data from 2004 to 2011. The dependent variable is the share of innovative entrepreneurship in a particular country in a particular year. The variable is calculated from the individual-level variable innovative entrepreneur and measures the aggregate number of innovative entrepreneurs as a percentage of all entrepreneurs per country. We included countrylevel main and control variables in line with Braunerhjelm and Eklund (2014). Such panel data investigations are only possible at the country and not at the individual level, because the individual-level GEM dataset is not a panel dataset; every year, it uses a different or new sample of individuals (Reynolds et al. 2005).

We analyze our country-level dataset through both a fixed effect panel data regression and a first-difference regression. The first-difference regression is estimated in a Bayesian way. The main reason is that first differencing reduces the number of observations per country substantially making classical null hypothesis significance testing difficult. Bayesian analysis, in turn, exploits fully the information provided in small samples. It is able to investigate the relationships between variables using small samples; sample size does not influence its ability to test whether a particular relationship is "true" or not (see Block et al. (2014), for a deeper discussion of Bayesian analysis).

\section{Results}

\subsection{Descriptive statistics}

Before we describe our main results, we present descriptive statistics and correlations for the variables used in our study (Table A.3 in the electronic supplementary material). Eighteen percent of the entrepreneurs are innovative and introduce new products or services to the market. Forty-nine percent of the entrepreneurs have a university education, $3 \%$ have recent prior entrepreneurship experience, and $37 \%$ have another entrepreneur in 


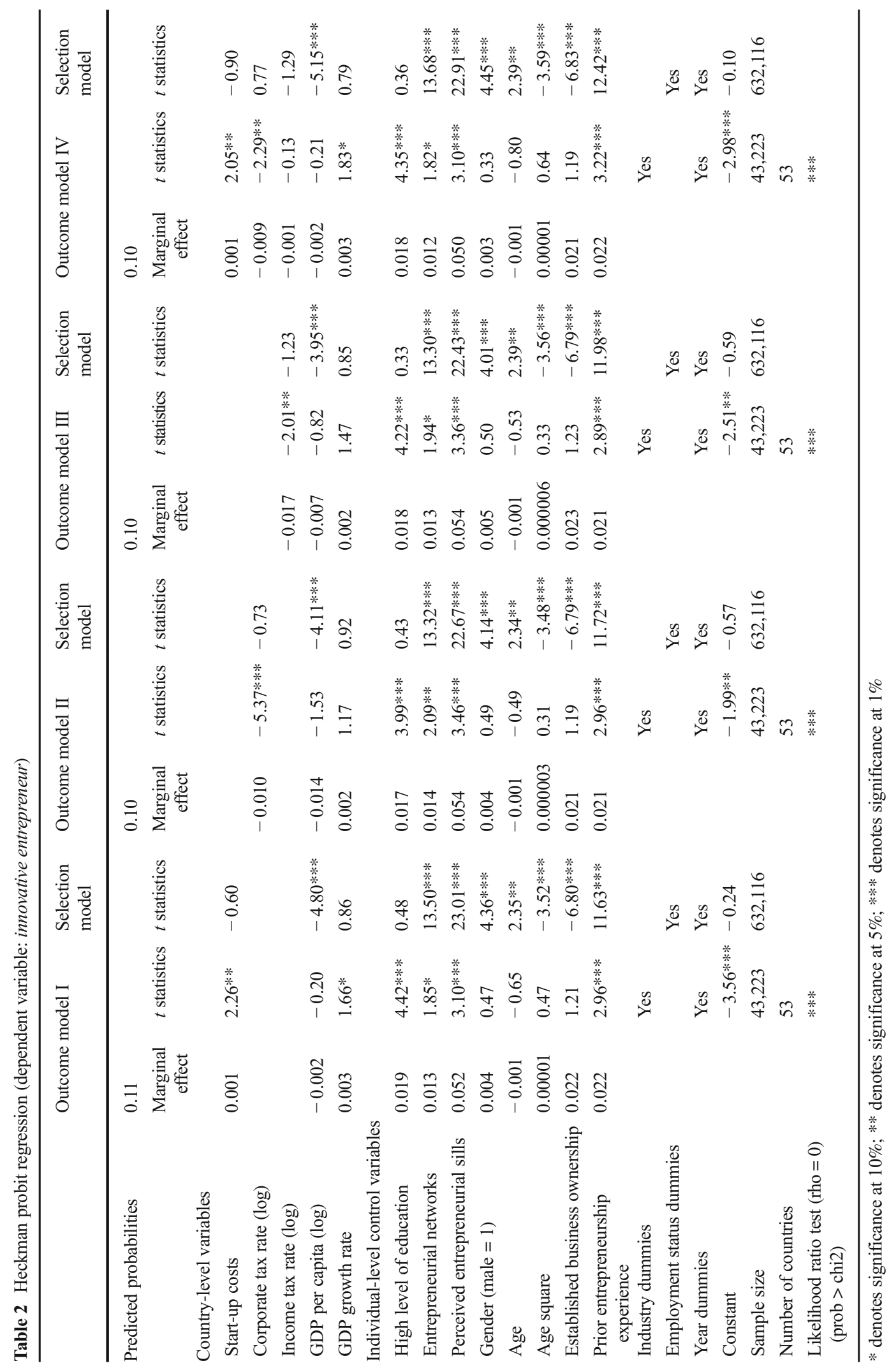


their networks. Regarding country-level indicators, it takes on average $9 \%$ of a person's income (measured as GDP per capita) to register a company. Mean corporate and personal income tax rates are 27 and 32\%, respectively.

The correlation matrix shows that the correlations between individual-level variables are low. Regarding macro level variables, we find high correlations between log GDP per capita and start-up costs (correlation is 0.65 ), as well as between corporate and personal income tax rates (correlation is 0.48). In light of these high correlations, we adopt a stepwise approach in our regression analysis.

4.2 Individual-level cross-sectional regressions:

Heckman probit model

\subsubsection{Main findings}

Table 2 presents the Heckman probit regression results. We find a significant positive relationship between the start-up costs and the entrepreneurs' likelihood to innovate (model I in Table 2). We find a marginal effect of $0.1 \%$ point. That is, evaluated at sample means, a $10 \%-$ point increase in start-up costs from the mean leads to an increase in the predicted probability of innovative entrepreneurship of $1 \%$ point-an increase of $9.8 \%$.

Our results (model II and model III in Table 2) further show an overall significant negative relationship between the corporate and personal tax rates and the entrepreneurs' likelihood to innovate. We find a marginal effect of $-1 \%$ point for the variable corporate tax rate $(\log )$. That is, evaluated at the sample mean, a $10 \%$ point decrease in a country's corporate tax rates from the mean leads to an increase in the predicted probability of innovative entrepreneurship of $0.6 \%$ points - an increase of approximately $6 \%$. Moreover, we find a significant marginal effect of $-1.7 \%$ points for the variable personal income tax rate (log). When all independent variables (i.e., start-up costs and taxes) are included simultaneously (model IV in Table 2), we see that the results for start-up costs and corporate taxes remain significant, but the income tax rate variable becomes insignificant.

\subsubsection{Findings regarding control variables}

At the country level, GDP growth and log GDP per capita have insignificant associations with the entrepreneurs' likelihood to innovate. At the individual level, a high level of formal education, knowing another entrepreneur, prior entrepreneurship experience, and (perceived) entrepreneurial skills have significant positive associations with the entrepreneurs' propensity to innovate. Among these variables, the perception of entrepreneurial skills seems to have the strongest relationship with innovation (a marginal effect of $5.4 \%$ points).

The selection model indicates that start-up costs and tax rates are not significantly related to entrepreneurial entry of individuals. At the country level, only log GDP per capita consistently shows a significant negative relationship with entry into entrepreneurship. At the individual level, prior entrepreneurship experience, perception of entrepreneurial skills, having entrepreneurial networks and being male show significant positive relationships with the individuals' likelihood to become an entrepreneur. Being an established business owner and being of advanced age relate negatively to entry into entrepreneurship.

\subsection{Country-level longitudinal regressions}

\subsubsection{Fixed effect panel data regression}

Our fixed effect panel data regression results are presented in Table 3. As this analysis is conducted at the country level, we use "share of innovative entrepreneurship" rather than "innovative entrepreneur" as outcome variable. We find that only corporate tax rate has a statistically significant

Table 3 Fixed effect panel regressions at the country level (dependent variable: share of innovative entrepreneurship)

\begin{tabular}{ll}
\hline Country-level variable & Coefficient (standard error) \\
\hline Start-up costs & $0.001(0.001)$ \\
Corporate tax rate $(\log )$ & $-0.060 *(0.030)$ \\
Income tax rate $(\log )$ & $0.017(0.023)$ \\
GDP per capita $(\log )$ & $0.040(0.035)$ \\
GDP growth rate & $-0.001(0.001)$ \\
Country clustered standard errors & Yes \\
Constant & $-0.099(0.355)$ \\
Number of countries & 53 \\
Number of observations & 276 \\
$R^{2}$ & 0.06 \\
\hline
\end{tabular}

$*$ denotes significance at $10 \% ; *$ denotes significance at $5 \%$; *** denotes significance at $1 \%$ 
Table 4 Summary of main findings

\begin{tabular}{|c|c|c|c|}
\hline \multirow[b]{2}{*}{ Regression type } & \multicolumn{2}{|c|}{ Within countries (longitudinal investigation) } & \multirow{2}{*}{$\begin{array}{l}\text { Between countries (cross-sectional investigation) } \\
\text { Heckman probit regression }\end{array}$} \\
\hline & Fixed effect panel regression & $\begin{array}{l}\text { Bayesian first-difference } \\
\text { regression }\end{array}$ & \\
\hline \multicolumn{4}{|l|}{ Variable } \\
\hline Start-up costs & Insignificant coeff. & Negative coefficient & Positive and significant coeff. \\
\hline Corporate tax rate & Negative and significant coeff. & Negative coefficient & Negative and significant coeff. \\
\hline Income tax rate & Insignificant coeff. & Positive coefficient & Insignificant coeff. \\
\hline
\end{tabular}

Coeff. coefficient

(negative) relationship with the share of innovative entrepreneurship. Start-up costs and income tax rate do not have statistically significant relationships with the share of innovative entrepreneurship.

\subsubsection{Bayesian first-difference regression}

In order to take out any spurious correlation that might be due to the non-stationarity of our time series data, we calculated the first differences (period-to-period change) of our regression variables and ran a simple pooled OLS model at the country level. The variables are the same as those in the fixed effect model (Table 3). Using first differences has led to a loss of $28 \%$ of our data points. For this reason, we ran the first-difference regression in a Bayesian way. The results are as follows: the mean coefficient of corporate tax rate is -0.055 , and the probability of a positive effect is $17.44 \%$; the mean coefficient of income tax rate is 0.033 , and the probability of a positive effect is $76.26 \%$; the mean coefficient of start-up costs is -0.001 , and the probability of a positive effect is $13.60 \%{ }^{2}$

Table 4 summarizes our main results. Corporate taxes show a negative relationship with innovative entrepreneurship in all three types of regressions. This is not true for income taxes, which seem to have little relationships with innovative entrepreneurship. High start-up costs show a positive relationship with innovative entrepreneurship in cross-sectional regressions but not in longitudinal regressions.

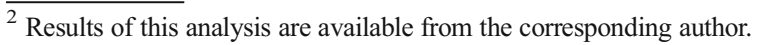

4.4 Robustness checks and further analyses

\subsubsection{Inclusion of other control variables in individual-level regressions}

To further check the robustness of our results, we included a number of country-level control variables used in prior research. Due to having a sample of only 53 countries, we added these control variables once at a time and replace one of the current control variables. Table A.5 in the electronic supplementary material summarizes the results of these robustness tests. As can be seen, in most cases, the results are robust.

Among others, we looked into the role of country-level insolvency costs. To do so, we added the insolvency costs (as a percentage of estate) from World Bank Doing Business data to the as a further country-level control variable to the individual-level Heckman regressions. The original results were robust suggesting that corporate tax rate shows a negative significant relationship and start-up costs show a positive significant relationship with innovative entrepreneurship (Table A.5 in the electronic supplementary material). Insolvency costs show no significant relationship with innovative entrepreneurship. We further find that corporate tax rate and insolvency costs have low correlations and that no interaction effects exist.

Lastly and looking into the level of formal versus informal entrepreneurial activities in a country, we find that when we add high formal rate of entrepreneurship as a control variable, the results are partially robust. Corporate tax rate still shows a significant negative relationship with innovative entrepreneurship. Moreover, we interacted the formal rate of entrepreneurship with start-up costs and with corporate tax rate. We find that there is no difference between countries with high rates versus countries with low rates of formal 
entrepreneurship regarding the effects of start-up costs on innovative entrepreneurship. However, the formal entrepreneurship interaction term with corporate tax rate suggests that in countries with high formal entrepreneurship rates, the effects of corporate tax rate on innovative entrepreneurship are more pronounced.

\subsubsection{Multilevel regressions}

The likelihood ratio test results that are provided in Table 2 show that a Heckman model is necessary due to the existence of a selection bias. Still, we ran multilevel regressions as a further robustness check. Such multilevel regressions are specifically designed to investigate hierarchical level data taking into account possible intraclass correlations. The multilevel logit regressions show similar results as the Heckman probit regressions (Table A.6 in the electronic supplementary material). Using these models, we also find that start-up costs have a significant positive relationship to the entrepreneurs' probability for being innovative and that corporate and income tax rates have a significant negative association with the likelihood of innovative entrepreneurship.

\section{Discussion and conclusions}

\subsection{Summary and interpretation of main results}

Our results support the conclusion that start-up costs and tax rates can have strong relationships with innovative entrepreneurship. Our cross-country analysis shows that start-up costs have a significant positive relationship with the entrepreneurs' propensity to innovate. At first sight, this seems against the findings of prior studies, which found a negative relationship between start-up regulations and entrepreneurial entry (De Soto 1989; Djankov et al. 2002; Klapper et al. 2006). We interpret our finding as evidence for the need to distinguish between different types of entrepreneurship when investigating the effects of deregulation on entrepreneurship. While reducing start-up costs may lower the barriers to entry and increase the quantity of entrepreneurship, it may not necessarily have a positive effect on the quality of entrepreneurship. In fact, as our results show, countries with high levels of start-up costs seem to have a higher share of innovative entrepreneurship.

Our finding that start-up costs hamper innovative entrepreneurship is only confirmed in our cross- sectional and not in our longitudinal investigations. However, when a country changes its start-up costs, this will not immediately have an effect on the share of innovative entrepreneurs in that country. One potential explanation for this is that start-up costs often do not come alone but are correlated with other entry regulations (e.g., time required to start a business) (van Stel et al. 2007; Branstetter et al. 2014). While the level of start-up costs has gone down noticeably between 2004 and 2011, the time needed to start a new business is still considerably high (around 43 days for upper middle income countries in 2011). ${ }^{3}$ Furthermore, and in line with Estrin et al. (2013), it could be that the time period (from 2004 to 2011) is too short to see longitudinal effects of changes in institutions such as start-up costs. While we often see changes in the start-up costs in this period (Table A.2 in the electronic supplementary material), organizations behind start-up regulations such as the chamber of commerce usually take much more time to change (Van de Vliert et al. 2016). Such organizations may reduce start-up costs in a short period, but other regulations (e.g., administrative procedures) as well as informal institutions around start-up costs (e.g., norms and culture) change with a much slower pace (Fritsch and Wyrwich 2018).

We find that corporate taxes have a negative relationship with innovative entrepreneurship while there seems to be little effect of income taxes. How can we explain these differing effects? As noted previously, one important difference between corporate and personal income tax is that the personal income tax scheme typically allows deducting losses from other income while this is not possible for corporate losses (Cullen and Gordon 2007). Thus, while both types of tax take away part of the entrepreneurial income, unincorporated firms are insured through personal income tax schemes while incorporated firms do not have such an insurance. Hence, the deterring effect of high taxes for innovative entrepreneurship is higher for corporate versus income taxes.

Moreover, high corporate tax rates can be considered for incorporated firms as decreasing their financial resources available for investments in innovation. Technology start-ups, which are often incorporated firms, often depend on their own financial resources for developing new products and ideas in early stages. The

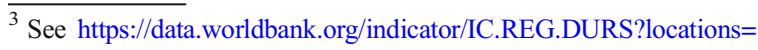
XT (accessed September 2017).
} 
situation is different for many unincorporated firms. The entrepreneurs behind these firms, which are often sole proprietors, freelancers, or part-time entrepreneurs do not have such a strong growth agenda and thus do not invest so heavily in innovation. A cut in income tax does not change their agenda or goals and will not have a profound effect on their investments in innovation. Reductions in income taxes should thus not increase the share of innovative entrepreneurship in a country.

Finally, incorporated firms typically rely more on external financing such as venture capital compared with unincorporated firms. In fact, the reason why they are incorporated might be that they want to attract venture capital or other forms of external financing. High corporate tax rates reduce the expected returns on innovative ventures and subsequently decrease venture capital investments in innovative start-ups (Djankov et al. 2010). Prior research shows that the inflow of venture capital investments is linked to start-up and industry innovation (Kortum and Lerner 2000). A similar argument can be made with regard to the inflow of foreign direct investment. Heavy taxation is shown to have an adverse influence on the inflow of foreign direct investment (Djankov et al. 2010). Foreign investors normally bring their knowledge, experience, and technologies, along with their money, to the countries in which they invest (De Clercq et al. 2008), spurring start-up innovation.

\subsection{Policy implications}

To date, little scholarly attention has been devoted to the influence of the costs imposed by regulations on innovative entrepreneurship. Regulations are typically not considered as a source of costs that take away the prize of entrepreneurial innovation. Although studies investigated the influence of institutions and regulations on the level and the type of entrepreneurship (Cullen and Gordon 2007; Branstetter et al. 2014), it is unclear, particularly at the micro-level, how innovative entrepreneurship is affected. Our article sheds light on this issue. Our main argument is premised on the notion that entrepreneurs innovate mainly to gain above-average profit margins, in line with Schumpeter's proposition (1934). In this context, the government can stimulate entrepreneurial innovation by using appropriate business regulations to structure the relative rewards for innovation (Baumol 1990).

Some policy implications can be derived from our findings. Firstly, there seems to be an important difference between one-off costs (start-up costs) and recurring costs (taxes) imposed by regulations on entrepreneurial behavior. Entrepreneurs seem to perceive start-up costs as one-off entry costs, and if they believe in the promise of their ideas and in future returns on their venture, they are willing to incur such costs to start their business. Entrepreneurs, however, view corporate taxes as recurring costs that come back every period and take away part of their income. Every period that entrepreneurs calculate their revenue and expenses, they see such tax payments as costs that reduce their net profit and take away the money they need to further developing their ideas. Secondly, our crosssectional investigations show that start-up costs have a significant positive relationship with the entrepreneur's likelihood to be innovative. This finding suggests that policy-makers should carefully consider the consequences of lowering start-up costs. The quality of entrepreneurship might in fact go down as a result. The reason is that it becomes easier for entrepreneurs with not so promising ideas to enter the market. Lowering start-up costs may reduce the entry barriers to start a business but our findings suggest that it is not effective as a tool to motivate individuals with innovative ideas to become entrepreneurs. Thirdly, the government can stimulate innovative entrepreneurship by tying costs less directly to the rewards of innovation. For example, and in line with Baumol et al. (2007), tax on properties and goods is preferred to tax on profit if the goal is to promote innovative business activities and growth. The results of our paper are in accordance with this argument. We find that when countries reduce the level of corporate taxes, innovative entrepreneurship is stimulated. Yet, this effect was not found for personal income taxes. We conclude that changes in corporate tax levels are a more effective tool than changes in personal income taxes to promote innovative entrepreneurship. There has been a lot of discussion and competition between countries on reducing the corporate tax rate (Djankov 2017). The most recent discussion is in the USA, where the corporate tax rate is relatively high and has not been changed for the past 30 years. Our results suggest that a cut in corporate tax rates may indeed favor innovative entrepreneurship, which is an important source of economic growth (Schumpeter 1934; Block et al. 2017). This result of our study is in line with two recent papers calculating the impacts of the proposed tax reform of the US government. Bhattarai et al. (2017) and Haughton et al. (2017) simulate the impacts of the proposed cut in the corporate income tax rate and find that corporate investments and capital formation will increase. In particular, innovative industries such as machinery and instruments as well as the computer sector will benefit. The 
results of the two studies, however, also show that this proposed tax reform comes with two important negative side effects: first, the income gap between rich and poor households in the USA will rise (even further), and second, there will be a huge budget deficit of the US government.

\subsection{Limitations and further research}

This study has a number of limitations that need to be taken into account. Using an objective measure of innovation (e.g., new product sales as a percentage of total sales) would be preferred to the self-reported measure used in this study. However, access to such data in a cross-country setting that includes enough observations for each country would be difficult, if not impossible to obtain. Another limitation concerns the relatively low within-country variation of our independent variables (Table A.2), which reduces the power of our longitudinal investigations. It would be great to use a larger time span with hopefully more within country variation for our fixed effect regressions. Finally, we should note that our research design cannot completely rule out endogeneity concerns. It is conceivable that our (most robust) finding regarding the relationship between corporate tax rate and innovative entrepreneurship is in fact driven by an omitted variable that is correlated with both corporate taxes and innovative entrepreneurship. As we have carefully tried to rule out such a concern in our cross-sectional individual-level regressions (see Table A.5), we do not have such a possibility in our longitudinal regressions. For this, we would need a valid and statistically strong instrumental variable and/or an individual-level panel dataset spanning over several decades and countries. The paper by Hansson (2012) is a nice example of a study with such a robust and preferable research design. The study investigates the relationship between income taxes and the decision to become self-employed using a large, representative household level panel dataset from Sweden spanning in total 16 years of data.

We would like to highlight four main avenues for future studies. First, one could investigate how such one-off versus recurring costs resulting from regulations and taxes influence the innovativeness of important sub-groups of entrepreneurs such as female entrepreneurs (Dilli and Westerhuis 2018), part-time entrepreneurs (Block and Landgraf 2016; Schulz et al. 2016), and solo selfemployed (van Stel and de Vries 2015). Entrepreneurs are a very heterogeneous group, and it is valuable to study important sub-groups. Second, it would be interesting to investigate the impact of other regulations, such as labor regulations on the entrepreneurs' propensity to innovate, and how they moderate the effects of start-up costs and taxes. High costs imposed by labor regulations, for example, may increase the costs of innovation because innovation is often accompanied with labor adjustments (Scarpetta and Tressel 2004), though such costs may also discourage the entry of entrepreneurs with not so promising ideas. Third, we look in our study at only one type of innovation, namely product innovation. Further research could investigate the relationship between tax rates and other types of innovation. High tax rates, for example, may stimulate entrepreneurs to buy new machinery and declare it as a cost to avoid high tax payments, hence increasing the likelihood of process innovation. Fourth, it would be interesting to look at the effects of start-up costs and taxes on other innovation entrepreneurship-related outcome variables. While our study investigates how start-up costs and taxes are related to the rate of innovative entrepreneurship, we do not investigate how successful and sustainable these newly created innovative ventures in fact are. It might be that a drastic cut in corporate taxes not only has the already widely discussed negative side effects on societal inequality and governmental budget deficit (Bhattarai et al. 2017; Haughton et al. 2017) but also pushes individuals into innovative entrepreneurship that would actually be "better off" working as a paid employee in an established firm.

Open Access This article is distributed under the terms of the Creative Commons Attribution 4.0 International License (http:// creativecommons.org/licenses/by/4.0/), which permits unrestricted use, distribution, and reproduction in any medium, provided you give appropriate credit to the original author(s) and the source, provide a link to the Creative Commons license, and indicate if changes were made.

\section{References}

Acs, Z., \& Audretsch, D. (1987). Innovation, market structure and firm size. The Review of Economics and Statistics, 69(4), 567-574. https://doi.org/10.2307/1935950.

Anokhin, S., \& Schulze, W. S. (2009). Entrepreneurship, innovation, and corruption. Journal of Business Venturing, 24(5), 465-476. https://doi.org/10.1016/j.jbusvent.2008.06.001.

Autio, E., Kenney, M., Mustar, P., Siegel, D., \& Wright, M. (2014). Entrepreneurial innovation: the importance of context. Research Policy, 43(7), 1097-1108. https://doi. org/10.1016/j.respol.2014.01.015.

Balliamoune-Lutz, M., \& Garello, P. (2014). Tax structure and entrepreneurship. Small Business Economics, 42(1), 165190. https://doi.org/10.1007/s11187-013-9469-9. 
Baumol, W. J. (1990). Entrepreneurship: productive, unproductive, and destructive. Journal of Political Economy, 98(5), 893-919. https://doi.org/10.1016/0883-9026(94)00014-x.

Baumol, W. J., Litan, R. E., \& Schramm, C. J. (2007). Good capitalism, bad capitalism and the economics of growth and prosperity. New Haven: Yale University Press. https://doi.org/10.2139/ssrn.985843.

Bhattarai, K., Haughton, J., Head, M., \& Tuerck, D. G. (2017). Simulating corporate income tax reform proposals with a dynamic CGE model. International Journal of Economics and Finance, 9(5), 20-35.

Blackburn, R. A., \& Schaper, M. T. (2016). Government, SMEs and entrepreneurship development. London: Routledge. https://doi.org/10.4324/9781315585666.

Block, J. (2016). Corporate income taxes and entrepreneurship activity. IZA World of Labor. https://doi.org/10.15185 /izawol.257.

Block, J., \& Landgraf, A. (2016). Transition from part-time entrepreneurship to full-time entrepreneurship: the role of financial and non-financial motives. International Entrepreneurship and Management Journal, 12(1), 259282. https://doi.org/10.1007/s11365-014-0331-6.

Block, J., Miller, D., \& Wagner, D. (2014). Bayesian methods in family business research. Journal of Family Business Strategy, 5(1), 97-104. https://doi.org/10.1016/j. jfbs.2013.12.003.

Block, J., Fisch, C., \& van Praag, M. (2017). The Schumpeterian entrepreneur: a review of the empirical evidence on the antecedents, behavior, and consequences on innovative entrepreneurship. Industry and Innovation, 24(1), 61-95. https://doi.org/10.1080/13662716.2016.1216397.

Branstetter, L., Lima, F., Taylor, L. J., \& Venâncio, A. (2014). Do entry regulations deter entrepreneurship and job creation? Evidence from recent reforms in Portugal. The Economic Journal, 124(577), 805-832. https://doi.org/10.1111/ecoj.12044.

Braunerhjelm, P., \& Eklund, J. E. (2014). Taxes, tax administrative burdens and new firm formation. Kyklos, 67(1), 1-11. https://doi.org/10.1111/kykl.12040.

Bruce, D., \& Mohsin, M. (2006). Tax policy and entrepreneurship: new time series evidence. Small Business Economics, 26(5), 409-425. https://doi.org/10.1007/s11187-005-5602-8.

Bruhn, M. (2011). License to sell: the effect of business registration reform on entrepreneurial activity in Mexico. The Review of Economics and Statistics, 93(1), 382-386. https://doi.org/10.1596/1813-9450-4538.

Chatterji, A., Glaeser, E., \& Kerr, W. (2014). Clusters of entrepreneurship and innovation. Innovation Policy and the Economy, 14(1), 1-20. https://doi.org/10.1086/674023.

Clingingsmith, D., \& Shane, S. (2016). How individual income tax policy affects entrepreneurship. Fordham Law Review, 84, 2495-2516.

Cullen, J. B., \& Gordon, R. H. (2007). Taxes and entrepreneurial risk-taking: theory and evidence for the U.S. Journal of Public Economics, 91(7-8), 1479-1505. https://doi. org/10.1016/j.jpubeco.2006.12.001.

Davidsson, P., \& Honig, B. (2003). The role of social and human capital among nascent entrepreneurs. Journal of Business Venturing, 18(3), 301-331. https://doi.org/10.1016/s08839026(02)00097-6.

De Clercq, D., Hessels, J., \& Van Stel, A. J. (2008). Knowledge spillovers and new ventures' export orientation. Small
Business Economics, 31(3), 283-303. https://doi. org/10.1007/s11187-008-9132-z.

De Meza, D., \& Webb, D. C. (1999). Wealth, enterprise and credit policy. The Economic Journal, 109(455), 153-163. https://doi.org/10.1111/1468-0297.00424.

De Soto, H. (1989). The other path: the invisible revolution in the third world. New York: Harper and Row. https://doi. org/10.2307/20043955.

DeVries, N., \& Koster, S. (2013). Determinants of innovative solo self-employment: a regional approach, In: EIASM, ECSB and ISM: RENT XXVII conference (Research in Entrepreneurship and Small Business), Book of abstracts, Vilnius: ISM, p. 54.

Desai, M., Gompers, P., \& Lerner, J. (2003). Institutions, capital constraints and entrepreneurial firm dynamics: evidence from Europe. NBER Working Paper No. 10165. https://doi. org/10.3386/w10165.

Dilli, S., \& Westerhuis, G. (2018). Institutions, gender differences in human capital, and entrepreneurship. Small Business Economics. https://doi.org/10.1007/s11187-018-0004-x.

Djankov, S. (2017). Corporate tax cuts: examining the record in other countries. Peterson Institute for International Economics, Paper no. PB17-14.

Djankov, S., La Porta, R., Lopez-de-Silanes, F., \& Shleifer, A. (2002). The regulation of entry. Quarterly Journal of Economics, 117(1), 1-37. https://doi.org/10.1162 /003355302753399436.

Djankov, S., Ganser, T., McLiesh, C., Ramalho, R., \& Shleifer, A. (2010). The effect of corporate taxes on investment and entrepreneurship. American Economic Journal: Macroeconomics, 2, 31-64. https://doi.org/10.1257 /mac.2.3.31.

Dreher, A., \& Gassebner, M. (2013). Greasing the wheels? The impact of regulations and corruption on firm entry. Public Choice, 155(3), 413-432. https://doi.org/10.1007/s11127011-9871-2.

Estrin, S., Korosteleva, J., \& Mickiewicz, T. (2013). Which institutions encourage entrepreneurial growth aspirations? Journal of Business Venturing, 28(4), 564-580. https://doi. org/10.1016/j.jbusvent.2012.05.001.

Fölster, S. (2002). Do lower taxes stimulate self-employment? Small Business Economics, 19(2), 135-145. https://doi. org/10.1023/a:1016200800982.

Fritsch, M., \&Wyrwich, M. (2018). Regional knowledge, entrepreneurial culture and innovative start-ups over time and space-an empirical investigation. Small Business Economics. https://doi.org/10.1007/s11187-018-0016-6.

Gentry, W., \& Hubbard, G. (2000). Tax policy and entrepreneurial entry. The American Economic Review, 90(2), 283-287. https://doi.org/10.1257/aer.90.2.283.

Gregg, D., \& Parthasarathy, M. (2017). Factors affecting the longterm survival of eBay ventures: a longitudinal study. Small Business Economics, 49, 405-419. https://doi.org/10.1007 /s11187-017-9846-x.

Haans, R., \& van Witteloostuijn, A. (2016). Expected job creation across the cultural industries: a sectoral division and its implications for cultural policy. International Journal of Cultural Policy, 24, 1-24. https://doi.org/10.1080 $/ 10286632.2015 .1128420$.

Hallen, B., \& Eisenhardt, K. M. (2012). Catalyzing strategies and efficient tie formation: how entrepreneurial firms obtain 
investment ties. Academy of Management Journal, 55(1), 35-70. https://doi.org/10.5465/amj.2009.0620.

Hansson, A. (2012). Tax policy and entrepreneurship: empirical evidence from Sweden. Small Business Economics, 38(4), 495-513. https://doi.org/10.1007/s11187-010-9282-7.

Harhoff, D., Stahl, K., \& Woywode, M. (1998). Legal form, growth and exit of West German firms - empirical results for manufacturing, construction, trade and service industries. The Journal of Industrial Economics, 46(4), 453-488. https://doi.org/10.1111/1467-6451.00083.

Haughton, J., Backman, K., Bhattarai, D., Tuerck, G. (2017). Distribution effects of the Trump and Clinton tax proposals. Atlantic Economic Journal, 1-20.

Heckman, J. (1976). The common structure of statistical models of truncation, sample selection, and limited dependent variables, and a simple estimator for such models. Annals of Economic and Social Measurement, 5, 475-492.

Heckman, J. J. (1979). Sample Selection Bias as a Specification Error. Econometrica, 47(1), 53-161.

Henrekson, M., \& Sanandaji, T. (2011). Entrepreneurship and the theory of taxation. Small Business Economics, 37(2), 167185. https://doi.org/10.1007/s11187-009-9242-2.

Hessels, J., van Gelderen, M., \& Thurik, R. (2008). Entrepreneurial aspirations, motivations, and their drivers. Small Business Economics, 31(3), 323-339. https://doi. org/10.1007/s11187-008-9134-x.

Ho, Y., \& Wong, P. (2007). Financing, regulatory costs and entrepreneurial prosperity. Small Business Economics, 28(2), 187-204. https://doi.org/10.1007/s11187-006-9015-0.

Huber, J. D., \& Stanig, P. (2011). Church-state separation and redistribution. Journal of Public Economics, 95(7-8), 828836. https://doi.org/10.1016/j.jpubeco.2011.02.001.

Kamleitner, B., Korunka, C., \& Kirchner, E. (2012). Tax compliance of small business owners: a review. International Journal of Entrepreneurial Behavior and Research, 18(3), 330-351. https://doi.org/10.1108/13552551211227710.

Kaplan, D. S., Piedra, E., \& Seira, E. (2011). Entry regulation and business start-ups: evidence from Mexico. Journal of Public Economics, 95(11-12), 1501-1515. https://doi.org/10.1016 /j.jpubeco.2011.03.007.

Klapper, L., Laeven, L., \& Rajan, R. (2006). Entry regulation as a barrier to entrepreneurship. Journal of Financial Economics, 82(3), 591-629. https://doi.org/10.1016/j. jfineco.2005.09.006.

Koellinger, P. (2008). Why are some entrepreneurs more innovative than others? Small Business Economics, 31(1), 21-37. https://doi.org/10.1007/s11187-008-9107-0.

Kortum, S., \& Lerner, J. (2000). Assessing the contribution of venture capital to innovation. RAND Journal of Economics, 31, 674-669.

La Porta, R., Lopez-de-Silanes, F., Shleifer, A., \& Vishny, R. W. (1999). The quality of government. Journal of Law, Economics, and Organization, 15(1), 222-279. https://doi. org/10.3386/w6727.

Lee, Y., \& Gordon, R. H. (2005). Tax structure and economic growth. Journal of Public Economics, 89(5-6), 1027-1043. https://doi.org/10.1016/j.jpubeco.2004.07.002.

Monteiro, J. C. M., \& Assunção, J. J. (2012). Coming out of the shadows? Estimating the impact of bureaucracy simplification and tax cut on formality in Brazilian microenterprises.
Journal of Development Economics, 99(1), 105-115. https://doi.org/10.1016/j.jdeveco.2011.10.002.

Puhani, P. (2000). The Heckman correction for sample selection and its critique. Journal of Economic Surveys, 14(1), 53-68.

Raffiee, J., \& Feng, J. (2014). Should I quit my day job? A hybrid path to entrepreneurship. Academy of Management Journal, 57(4), 936-963. https://doi.org/10.5465/amj.2012.0522.

Reynolds, P., Bosma, N., Autio, E., Hunt, S., De Bono, N., Servais, I., Lopez-Garcia, P., \& Chin, N. (2005). Global entrepreneurship monitor: Data collection design and implementation 1998-2003. Small Business Economics, 24(3), 205-231. https://doi.org/10.1007/s11187-005-1980-1.

Rostam-Afschar, D. (2014). Entry regulation and entrepreneurship: a natural experiment in German craftsmanship. Empirical Economics, 47(3), 1067-1101. https://doi. org/10.1007/s00181-013-0773-7.

Scarpetta, S., \& Tressel, T. (2004). Boosting productivity via innovation and adoption of new technologies: any role for labor market institutions? World Bank Working Papers. https://doi.org/10.2139/ssrn.535682.

Scarpetta, S., Hemmings, P., Tressel, T., Woo, J. (2002). The role of policy and institutions for productivity and firm dynamics: evidence from micro and industry data. OECD Economics Department Working Papers, No. 329, OECD Publishing. https://doi.org/10.2139/ssrn.308680.

Schulz, M., Urbig, D., \& Procher, V. (2016). Hybrid entrepreneurship and public policy: the case of firm entry deregulation. Journal of Business Venturing, 31(3), 272-286. https://doi. org/10.1016/j.jbusvent.2016.01.002.

Schumpeter, J. A. (1934). The theory of economic development. Cambridge: Harvard University Press. https://doi. org/10.1007/0-306-48082-4_3.

SRI International. (1999). International practices and experiences in business startup procedures. Arlington: SRI.

Suchman, M. C. (1995). Managing legitimacy: strategic and institutional approaches. Academy of Management Review, 20(3), 571-610. https://doi.org/10.5465/amr.1995.9508080331.

Thaler, R. H. (1999). Mental accounting matters. Journal of Behavioral Decision Making, 12(3), 183-206.

Van de Vliert, E., Janssen, O., \& Van der Vegt, G. (2016). Hard or easy? Difficult of entrepreneurial startups in 107 climateeconomic environment. Applied Psychology, 65(3), 469489. https://doi.org/10.1111/apps.12057.

Van Stel, A., \& de Vries, N. (2015). The economic value of different types of solo self-employed: a review. In The handbook of research on freelancing and self-employment ( $\mathrm{pp}$. 77-84). Dublin: Senate Hall Academic Publishing.

Van Stel, A., Storey, D. J., \& Thurik, A. R. (2007). The effect of business regulations on nascent and young business entrepreneurship. Small Business Economics, 28(2-3), 171-186. https://doi.org/10.1007/s11187-006-9014-1.

Wen, J. F., \& Gordon, D. V. (2014). An empirical model of tax convexity and self-employment. Review of Economics and Statistics, 96(3), 471-482. https://doi.org/10.1162/REST_ a 00388.

Yakovlev, E., \& Zhuravskaya, E. (2013). The unequal enforcement of liberalization: evidence from Russia's reform of business regulation. Journal of European Economic Association, 11(4), 808-838. https://doi.org/10.1111 /jeea.12026. 